\title{
RAICILLAS DE LA ANTIPOESÍA EN ATENEA DE 1939: LA GILET Y EL ÁNGEL MIEDOSO
}

\section{MARIO RODRÍGUEZ FERNÁNDEZ*}

$\mathrm{E}$ N EL AÑo 1939 Nicanor Parra publica en los números 168 y 174 de Atenea dos series de poemas: "Cantos cotidianos" y "Cantos paralelos", ambas de un libro próximo a publicarse que se titularía Dos años de melancolía que, de acuerdo al sistema de anuncios de títulos de libros futuros utilizados por Parra, nunca llegó a publicarse. Digo sistema porque reiteradas veces se anuncian títulos jamás concretados, como en 1942 se habla de un libro por aparecer titulado La luz del día, y diversos títulos para los que finalmente serían Poemas y antipoemas: Material de lectura, Pensamientos varios, A pan y agua, Entre las nubes silba la serpiente y Oxford 1950. El propio Parra frenaba sus impulsos por publicar: "Sobre todo porque yo sabía que cada libro de poesía que aparecía en Chile se medía con un solo metro: Neruda. Así como en física se habla de Ohm o de un Newton, en poesía se hablaba de un Neruda y se trataba de ver cuántos nerudas había en cada poeta nuevo. Por eso me resistía y seguía puliendo, buscando, investigando" (Binns, 2006: 913).

Esta necesidad, o "angustia de las influencias", que sentía Parra de diferenciarse de uno de los padres de la poesía chilena, lo llevó tal vez a inventar este sistema que, como él mismo afirma, formaba parte de la búsqueda de una voz diferente a la de Neruda.

* Profesor de Literatura, Departamento de Español, Facultad de Humanidades y Arte, Universidad de Concepción. Concepción, Chile. Correo: mariorod@udec.cl 
Pero también refiere a esa preocupación fundamental del antipoeta por encontrar títulos exactos, títulos que hablan por sí solos, para su producción poética. Es el caso emblemático de Poemas y antipoemas o de Obra gruesa, por ejemplo. El primer título, en una de sus acepciones, está basado en un modelo de la física: protones, electrones, cargas positivas y negativas; y el segundo en el de la agenda de la construcción de un edificio, metafóricamente el de la independencia de la antipoesía de los discursos nerudianos.

Tampoco se puede descartar que el sistema de anuncios sea una parodia de un cliché editorial, el de las próximas publicaciones.

Los títulos de los poemas que publicamos privilegian la palabra canto, perteneciente a una larga tradición literaria, que se inicia con los rapsodas griegos, y define al lenguaje poético como un decir semi-sagrado ("canta, oh musa, la cólera de Aquiles el pélida"). A ello Parra contrapone cualidades contrarias al canto como cotidianos y paralelos.

La acepción de cotidianos funciona escasamente en los poemas transcritos. Hay, sin embargo, enunciados que apuntan a una realidad despojada de fabulación, sea: "soy el mismo/ solitario estudiante de mi pueblo", o sea "la joven de la esquina por ejemplo". Pero, con reiteración, el yo se presenta bajo figuras que apuntan a un toque de imposibilidad: "triste corsario pensativo", "vagabundo doncel aventurero", "débil cantante del almendro", etc.

Paralelos parece, más bien, una mención irónica a la tradición excelsa del canto, especialmente porque no se ve ninguna correspondencia formal con la disposición del discurso poético. A lo mejor una podría ser el paralelismo musical entre "Fuga" y "Preludio" (título de los dos primeros poemas); o el que sean cuatro poemas que hablan sobre el mismo tema, el de la muerte.

En el nivel del lenguaje, estos poemas nos conectan con la consagrada influencia de García Lorca sobre la primera etapa de la obra de Nicanor Parra, especialmente la de Romancero gitano (1928) sobre Cancionero sin nombre (1937). Aunque hay mucho paño que cortar, parece ser una influencia incontestable. A propósito del "mucho paño", pienso, por ejemplo, que "El novio rencoroso" de Cancionero es una versión irónica de "La casada infiel" del Romancero.

Estos cantos cotidianos y paralelos, aunque no escapan de la órbita de García Lorca, la fracturan en algunos puntos. Uno de ellos es la ruptura con la métrica del Romancero y del Cancionero. El octosílabo imperante en ellos es sustituido por el endecasílabo que, según algunas conocidas tesis de Parra, es la métrica con que habla el pueblo, se escriben las noticias y está redactado El Quijote. 
Otro punto de diferenciación es la presencia potente de la subjetividad de un yo lírico, personal, a través de pronombres indicadores de esa subjetividad (yo, me, mi, etc.). En contraste, en el Romancero gitano los pronombres están enganchados a las esferas subjetivas de los distintos personajes que circulan por el texto: el niño, el jinete, el compadre, la niña muerta, la monja gitana, el gitano legítimo, Soledad Montoya, Antonio Torres Heredia, la madre, el emplazado. El único nombre posesivo que alude al sujeto de la enunciación lo encuentro en "Romance de la guardia civil española".

En Cancionero sin nombre también circulan personajes que hacen uso de la palabra: el matador, el novio rencoroso, el marido deficiente, la niña Chela, el hijo taimado, pero predomina un sujeto personal evidenciado mediante los marcadores pronominales, especialmente el me. El carácter de los personajes es muy curioso y distintivo del que poseen los yoes líricos del Romancero gitano. El matador, por ejemplo, no alude a la figura clásica de la Fiesta brava; no mata ningún toro, menos a alguien: "que yo no he matado a nadie". Aunque al final, se sabe que ha matado con una gilet a un ángel miedoso. El detalle de la gilet es curiosísimo. La hoja de afeitar reemplaza el arma clásica del matador, la espada, lo que indudablemente es un gesto irónico, paródico. Lo mismo sucede con los ángeles y el detalle del miedo. Todos los ángeles son miedosos, aunque uno al que mata es el más temeroso. La figura del matador asesinando a un ángel miedoso con una gilet es la contraria de los héroes asesinados en el Romancero. El pormenor de la gilet me parece que permite abrirse a la noción que Cancionero sin nombre es desde una perspectiva, tanto la del sujeto de la enunciación como del enunciado, un contracancionero. Como dije, me baso en un detalle clave: la hoja de afeitar, la gilet, que desplaza los puñales prestigiosos del Romancero. En la gilet está presente el desplazamiento de una tradición romántica sobre la muerte para colocar paródicamente en su lugar el espectáculo atrabiliario de perseguir y matar a un ángel miedoso con un adminículo para afeitarse.

Leer en clave semiseria o decididamente irónica los "Cantos cotidianos", puede ser plausible. En "Sinfonía", por ejemplo, no deja de ser risueña la figura del que enuncia presentándose como el fino joven de "nevada frente de marino". Más aún al contrastar que tal fino joven es, al mismo tiempo, "un triste corsario pensativo/ con un rojo clavel en el sombrero", y al final del poema "un vagabundo doncel aventurero". No puedo dejar de sonreírme de estas figuras del yo.

Tales transformaciones del sujeto y de sus actitudes en el transcurso del poema, es alegre, puro, solitario, triste, débil cantante, dormido, podrían en algún tipo de lectura ser interpretadas dentro del sistema que el surrealis- 
mo creó para las imágenes. Pero algunos detalles, como el adjetivo calificativo débil: "soy el débil cantante del almendro", ponen en duda esa lectura "seria". ¿Por qué débil?: Bastaría haber escrito soy el cantante del almendro; añadir "débil" es colocar una marca que envía a otras posibles lecturas al sobredeterminar las otras facetas del sujeto: es un fino joven, pero débil, un marino, un estudiante, un corsario, un vagabundo siempre débil, que apenas saca la voz. Indudablemente que hay aquí un juego irónico: presentarse como un sujeto casi desmayado, ofrecerse como un dormido, un vagabundo dormido, puede abrir, en contraposición a una lectura "seria" trascendental, otra risueña e irónica.

Tal es la propuesta que me atrevo a seguir con "Cantos cotidianos" y "Cantos paralelos".

En esta última serie el sesgo irónico es más marcado. En el poema "Fuga" la muerte se califica como una "moda" que se practica "con las manos cruzadas en el pecho". Y que a todos le toca, tanto a un señor como a "la joven de la esquina por ejemplo". El detalle del complemento del nombre "de la esquina" aterriza a la muerte, la coloca en el espacio cotidiano, confrontándola con el recurso paródico de la "moda" y, al mismo tiempo, autorizando la conclusión del poema: hay que encontrar un sistema para morir.

El sesgo irónico de estos versos permite darse cuenta que Nicanor Parra comienza tempranamente a buscar un lenguaje que le permita liberarse de la "angustia de las influencias" y merecer cincuenta años más tarde los elogios del propio Harold Bloom: "Ironista consumado Parra burla afablemente el proceso de la influencia, declinando convertirse en otro Neruda". (Bloom 2006: XXVII).

\section{REFERENCIAS}

Binns, N. (2006). Notas “Sobre Poemas y antipoemas". En Parra, N., Obras completas \& algo + (pp. 911-927). Edición supervisada por el autor, asesorada y establecida por Niall Binns al cuidado de Ignacio Echeverría. Prefacio de Harold Bloom. Prólogo de Federico Schopf. Barcelona: Galaxia Gutenberg.

Bloom, H. (2006). "Prefacio". En Parra, N., Obras completas \& algo + (pp. xxviIxxVIII). Edición supervisada por el autor asesorada y establecida por Niall Binns al cuidado de Ignacio Echeverría. Prefacio de Harold Bloom. Prólogo de Federico Schopf. Barcelona: Galaxia Gutenberg. 
NICANOR PARRA

Cantos cotidianos

SinfONIA

Soy el alegre joven, soy el fino poseedor del nardo y el silencio, en mi nevada frente de marino se detienen los ángeles del sueño.

Siempre de caracoles y abanicos mi corazón de par en par abierto, cada día que pasa, cada lirio purifica mi voz de jardinero.

Conocedor del trébol, soy el mismo solitario estudiante de mi pueblo, soy el triste corsario pensativo con un rojo clavel en el sombrero.

Yo no sé por qué vueltas del destino soy el débil cantante del almendro, una estrella radiante del rocío me ilumina de azul el pecho.

Soy el dueño del agua y el dormido vagabundo doncel aventurero, náufrago de altamar y del jacinto que me sigue los pasos como un perro. 


\section{Nocturno}

He de partir un día con el lirio derramado en la mano, dulcemente, dentro del corazón el mar umbrío y una ascensión de pájaros perennes.

Lejano y solo caeré dormido bajo la fría luna de noviembre sin oír la palabra de un amigo que me diga hasta luego para siempre.

He de caer un día convencido de mariposas y de sol ardiente con el símbolo claro del rocío y un empuje de flores en la frente.

He de partir lo sé, ya lo adivino, serio de caracol mi pie celeste, como jugando como de improviso muerto se cae un ángel en la nieve.

Ese día estaré como hoy tranquilo preparando una rosa transparente detenida la voz de veinte ríos en mi cansado corazón de siempre. 
Yo sé muy bien cómo se pasa dentro de un lirio, encadenado, sentir el peso del rocío sobre mi dos heridas manos.

Yo sé que todos algún día nos marcharemos sin soñarlo como se caen dulcemente las suaves hojas de los árboles.

Preguntará por mí un arcángel una mañana azul de mayo y con su clara compañía podré volar como los pájaros.

Nadie verá la fina huella de mi pie puro derramado ni soñarán que me he vestido con un eterno traje blanco.

Tú no comprendes que la lluvia como un diamante iluminado caiga del alto cielo umbrío sobre mis ojos de corsario.

Oigo las voces que me llaman de las raíces de los álamos, la fría luz de los metales como un amigo está esperándome.

Cuando su puerta de paloma mi corazón esté cerrando yo sólo quiero que me digas que no seré de ti olvidado. 


\section{FUGA}

Hay un modo muy fino de ponerse la corbata y un ángel en el cuello muy hermosa manera muy celeste de caer en las manos del silencio.

Yo sé bien lo que digo que se puede llegar a ser el jefe del almendro y quedarse dormido para siempre bajo un diáfano límite de espejos.

Qué cosa de marfil dirán ustedes y luego caerán como en ensueño hoy le toca al señor, mañana muere la joven de la esquina por ejemplo.

No hay para qué llorar que esta doliente moda, ha sido la misma en todo tiempo la practican en mar y continente con las manos cruzadas en el pecho.

Pero el mejor sistema me parece que debe ser caer sin aspavientos de manera que el día de la muerte nos parezca un antiguo compañero.

Yo mismo caeré sencillamente como quien va a coger un crisantemo y el amigo que quiera podrá verme con mi gesto habitual de jardinero 


\section{Preludio}

Con las manos caídas en la rosa me quedaré un buen día pensativo en un frío momento en una hora de gastados arcángeles y vidrios.

Los rumores lejanos de las cosas no cantarán como hoy en mis oídos ni el pesado lucero de la aurora podrá verse en mis ojos sumergido.

Sólo veré el volar de la paloma que huirá de mi pecho dividido con extendidas alas como rojas proporciones de hierros y jacintos.

Mil veces moriré más mil son pocas para olvidar mis días de marino y aunque sé que morir es mucha cosa me moriré gustoso en un navío.

En la nevada cumbre de la ola quedará lo mejor de lo que he sido con estrellada frente soñadora seguiré navegando sin destino. 
Coronadme la frente camaradas con un toro furioso de jacintos que una copa de nieve se derrama bajo mi libre pecho de bandido.

Yo sólo sé que caeré cantando con la luna quemada en el bolsillo y que a mi frente bajará en silencio la contenida mano de un amigo.

Algo debo decir, una palabra que como el aire sea o como un lirio una cosa lejana que recuerde mi solitaria vida de marino.

Oigo el ruido purísimo del agua penetrar como un ángel en mi oído y el galope lejano de un caballo que se pierde en el mar embravecido.

Todo lo que gané con la guitarra se lo dejo a la rosa y al rocío para que al pie de mi nevada tumba rueden eternamente como un río. 


\section{Canto final}

Uno se va muriendo suavemente con el canto del agua con el tiempo con la luna de oro con la nieve con la cosa que diga va muriendo.

Esta vida que tengo y que me tiene con ardiente cadena prisionero una tarde cualquiera será muerte muerte sin vuelta muerte sin remedio.

Lo que pasaba ayer pasará siempre como un ramo de flores como un sueño con el paso que dé, voy a la muerte poco a poco sin fin y sin quererlo.

Uno se va alejando fácilmente de lo que más anhela nuestro pecho y cuando menos piensa es cuando suele una tarde cualquiera caer muerto.

Y qué decir de mí que vivo enfrente de una lucha sin fin y de un almendro; en un límite de ánforas me tienen con las manos cruzadas en el pecho.

Aquí me tienen puro como siempre comparando la luna y el silencio que a este paso tan rápido de muerte mucho antes de morir estaré muerto. 